九州大学学術情報リポジトリ

Kyushu University Institutional Repository

\title{
Factors Affecting Recombinant Protein Yields in Insect Cell/Baculovirus Expression System
}

Tarui, Hiroshi

Microbial Genetics Division, Institute of Genetic Resources, Faculty of Agriculture, Kyushu University

Kawaguchi, Hiroyuki

Microbial Genetics Division, Institute of Genetic Resources, Faculty of Agriculture, Kyushu University

Kaneko, Shinji

Microbial Genetics Division, Institute of Genetic Resources, Faculty of Agriculture, Kyushu University

Hara, Toshio

Microbial Genetics Division, Institute of Genetic Resources, Faculty of Agriculture, Kyushu University

https://doi.org/10.5109/24092

出版情報: 九州大学大学院農学研究院紀要. 40 (1/2)，pp.45-51，1995-12. Kyushu University バージョン：

権利関係 : 


\title{
Factors Affecting Recombinant Protein Yields in Insect Cell/Baculovirus Expression System
}

\author{
Hiroshi Tarui, Hiroyuki Kawaguchi, Shinji Kaneko and Toshio Hara*
}

\author{
Microbial Genetics Division, Institute of Genetic Resources, Faculty of Agriculture, \\ Kyushu University, Fukuoka 812-81, Japan \\ (Received June 28, 1.995)
}

\begin{abstract}
The optimum conditions for the infection of Spodoptera frugiperda (Sf) 21 cells with recombinant virus were revealed. The maximum activity of Escherichiacoli ,3-galactosidase was obtained by using infected cells with 5th-passage recombinant virus. The repetition of passage for recombinant virus purification resulted in a sharp decrease in protein production, and the expressed enzyme activity with 11 th-passage virus dropped one fortieth of that with 5 th-passage. The $\beta$-galactosidase productivity by $\mathrm{Sf} 21$ cells infected in the exponential and stationary stages of growth was almost in the same level in final product yield, indicating the absence of a "culture age" effect. An increase in cell density on initial infection, moreover, did not result in a proportional increase in the final product levels. The increase in final product was observed for multiplicity of infection (MOI) values greater than 4 in cultures infected with recombinant virus. The maximum yield of recombinant protein occurred in Sf21 cells infected with an MOI of 10.
\end{abstract}

\section{INTRODUCTION}

The baculovirus expression system in insect cells constitutes a promising alternative to classical bacterial fermentation systems for the production of recombinant proteins, and is well suited to the large-scale production of valuable recombinant proteins. While some experiments have been done on the effects of initial cell density on baculovirus titers and polyhedrin levels (Stockdale and Gardiner, 1977; Murhammer and Goochee, 1988; Maiorella et al., 1988; Hink et al.,1990), very little is known pertaining to infection of $\mathrm{Sf2} 1$ cells with recombinant baculovirus.

In previous papers (Hara et al., 1992 and 1993), we reported that a cell line from Spodoptera frugiperda(IPLB-Sf21-AEII) is a good producer of Escherichiacoli $\beta$ galactosidase, that its productivity was greatly stimulated at $30^{\circ} \mathrm{C}$ and that the final product yield reached $7.1 \mathrm{mg} / \mathrm{ml}$, or more than $36 \%$ of the total cell proteins.

Previous work by other investigators suggests that some of the factors such as medium condition (Stockdale and Gardiner, 1977), cell density (Wood et al., 1982), and aeration (Wiss et al., 1986), may be important for optimizing recombinant protein synthesis in insect cell/baculovirous expression system. Lazarte et al. (1992) reported that the efficient recombinant protein production was achieved with extremely high MOI at 580. However, Schopf et al. (1990) reported that the MOI did not have a dramatic effect in the cells infected with the recombinant baculovirus. Licari and Bailey (1992) reported that maximum heterologous protein synthesis was dependent on the growth phase of the insect cells prior to infection.

\footnotetext{
*Corresponding author. Abbreviation: MOI, multiplicity of infection;p.i., postinfection.
} 
Maximization of the desired product is important in any biological process. The present paper describes the factors affecting the recombinant polyhedrin/ $\beta$-galactosidase yield in insect cell/baculovirus expression system.

\section{MATERIALS AND METHODS}

\section{Cell culture}

A cell line from Spodoptera frugiperda (IPLB-Sf 21-AEII) (Vaughu et al., 1977) was cultured in IPL-41 medium (Stockdale and Gardiner, 1977) supplemented with $10 \%$ fetal bovine serum (Gibco Labs., New York, USA). Cells were maintained as monolayers in stationary 25-ml TC flask (Falcon", Becton Dickinson Labware, New Jersey, U.S.A.) and infected with a recombinant virus at $27^{\circ} \mathrm{C}$. Cell counts were determined with the use of a hemacytometer on an optical microscope (Olympus Ltd., Tokyo; 10x eye piece and 40x objective). Viable cells were determined via trypan blue exclusion (Kuchler, 1977).

\section{Virus stock and infection}

A recombinant baculovirus, Ac360-501 $\beta$-gal, described previously (Hara et al., 1992), was used to infect Sf 21 cells. It contained the Escherichia coli lacZ gene of $\beta$ galactosidase. The fusion protein $(M \mathrm{r}=120 \mathrm{kDa})$ contsisted a segment of the polyhedrin protein fused with $\beta$-galactosidase. A virus stock solution was added to the monolayer of cell cultures at time zero after the medium was aspirated off from them. The cultures were placed on a rocking platform for $1 \mathrm{~h}$. After one additional hour, the medium was replaced with fresh one. In mock infected cell cultures, fresh medium was added in place of the viral inoculum.

Virus titer was determined using the end-point dilution method (Summers and Smith, 1987 ) by the addition of 5 -bromo-4-chloro- 3 -indoly- $\beta$-D-galactopyranoside to the medium.

\section{$\boldsymbol{\beta}$-Galactosidase assay}

The activity of $\beta$-galactosidase was determined by the $O$-nitrophenyl- $\beta$-Dgalactopyranoside (ONPG) assay (Miller, 1992). The ONPG (ZOO $\mu \mathrm{l})$ was added to 1,000 $\mu \mathrm{l}$ of Z-buffer $\left(16.1 \mathrm{~g} / \mathrm{L} \mathrm{Na} \mathrm{HPO}_{4} \mathrm{H}_{3} \mathrm{O}, 5.5 \mathrm{~g} / \mathrm{L} \mathrm{NaH}_{3} \mathrm{PO}_{4} \cdot \mathrm{H}_{3} \mathrm{O}, 0.75 \mathrm{~g} / \mathrm{L} \mathrm{KCl}, 0.246 \mathrm{~g} / \mathrm{L} \mathrm{MgSO}{ }_{+}\right.$ $\cdot 7 \mathrm{H}_{2} \mathrm{O}$ and $2.7 \mathrm{ml} / \mathrm{L} \beta$-mercaptoethanol) with $1 \mu \mathrm{l}$ of sample at $28^{\circ} \mathrm{C}$. The intracellular enzyme farction in the culture fluid was preparated by harvesting, suspending into water and disrupting cells with TOMY UD-201 (TOMY Co., Ltd., Tokyo, Japan). The conversion to 0-nitrophenyl was measured the absorption at $420 \mathrm{~nm}$ so that a faint yellow color developed for $1 \mathrm{~min}$ after the ONPG addition. The reaction was stopped with $500 \mu$ of 1 $\mathrm{M} \mathrm{Na}_{2} \mathrm{CO}_{3} . \quad \beta$-Galactosidase activity defined as follows: Units of $\beta$-galactosidase $=1000 \mathrm{X}$ $\mathrm{OD}_{\text {tw1 }} /$ time $(\mathrm{min}) /$ sample volume $(\mathrm{ml})$

\section{RESULTS}

Effect of serial passage of recombinant virus on $\beta$-galactosidase expression 

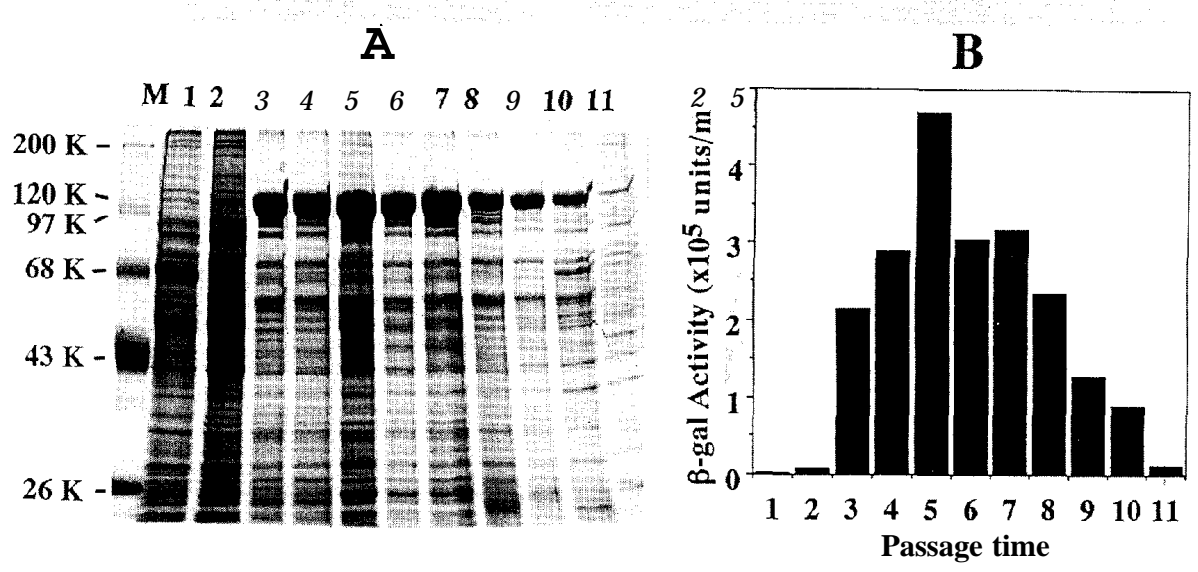

Fig. 1. Effect of Passage Number-of Recombinant Virus on $\beta$-Galactosidase Expression Level. (A) SDS-polyacrylamide gel electrophoresgram profiles of proteins produced by infected Sf2 1 cells. Sf 1 cells $\left(5.0 \times 10^{5}\right.$ cells $\left./ \mathrm{ml}\right)$ were infected with th addition of 0.5 -ml of a recombinant virus inoculum and incubated at $30^{\circ} \mathrm{C}$ for 4 days. Lysates of $2.3 \mathrm{X} 10^{4}$ cells were placed in each well. Uninfected cells (lane 1, mock) were similarly treated. Lanes 2-1 1 indicate passage numbers for recombinant virus purification from 1 to 11 , respectively. The molecular mass and positions of standard proteins (lane $\mathrm{M}$ ) are indicated to the left (myosin, $200 \mathrm{kDa}$; phosphorylase $b, 97.4 \mathrm{kDa}$; bovine serum albumin, $68 \mathrm{kDa}$; ovalbumin, $43 \mathrm{kDa}$; carbonic anhydrase, $29 \mathrm{kDa} ; \beta$-lactoglobulin, $18.4 \mathrm{kDa}$ ). (B) Intracellular $\beta$-galactosidase activity expressed by $\mathrm{Sf} 21$ cells which have been infected with virus at different passage numbers of recombinant virus. The enzyme activity was assayed according to the method of Miller (1972).

To investigate the effects of serial passage of recombinant virus on $\beta$-galactosidase expression, the total protein contents of infected Sf21 cells were determined by SDSpolyacrylamide gel electrophoresis (Fig. 1A). The amount of 120 -kDa proteins corresponding to $\beta$-galactosidase expressed by infected Sf2 1 cells with the 5th-passage time was the highest (lane 5, Fig. 1A). As shown in figure 1B, the intracellular activity of $\beta$-galactosidase expressed by $\mathrm{Sf} 21$ cells was the greatest when they were infected with the 5th-passage recombinant virus. However, when the virus was further passaged the protein production decreased. The enzyme activity level obtained with the 1 lth-passage virus was one fortieth of that obtained with the 5th-passage virus.

\section{Effect of cell growth stages on $\boldsymbol{\beta}$-galactosidase expression}

To determine the effects of cell growth stage on the production of $\beta$-galactosidase, replicate monolayer cultures of Sf21 cells $\left(1.5 \times 10^{7}\right.$ cells $\left./ \mathrm{ml}\right)$ were set up at $2 \times 10^{5}$ cells $/ \mathrm{ml}$ (Fig. 2A). Figure $2 \mathrm{~B}$ shows the effects of cell growth stage on $\beta$-galactosidase expression. Though the $\beta$-galactosidase productivity was strongly dependent on initial cell viability, the cell viabilities declined within days of the time of infection (data not shown). Sf21 cells which had been infected at the exponential (I and II, Fig. 2A) and stationary (III, IV and V, Fig. 2A) stages expressed the $\beta$-galactosidase almost in same 

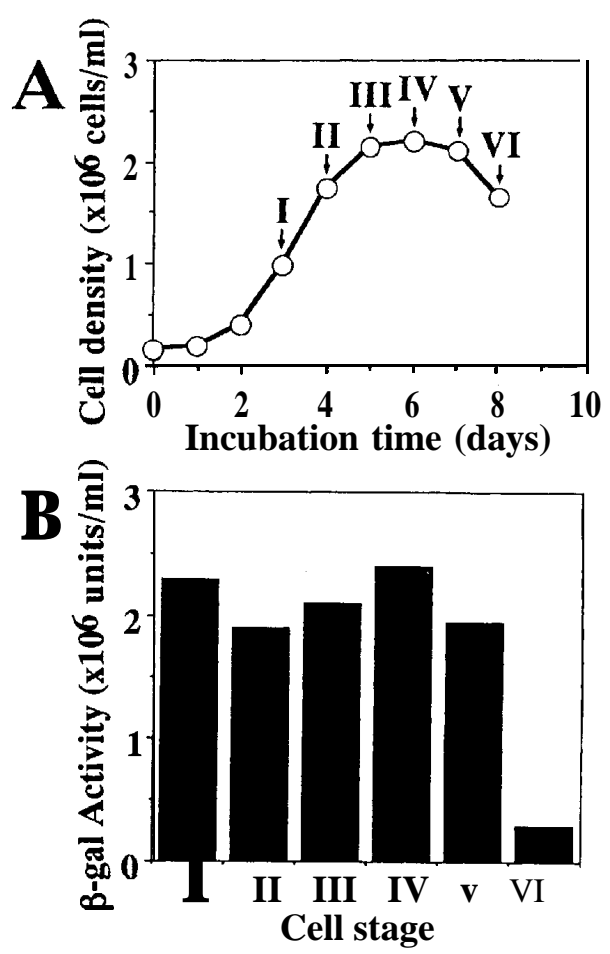

Fig. 2. Effect of Cell Stage on ,3-Galactosidase Expression Level.

(A) Sf2 1 cells $\left(5.0 \times 10^{5}\right.$ cell s/ ml) were cultured at $30^{\circ} \mathrm{C}$ for $3,4,5$, and 6 days, respectively. The arrow indicates the cell stage used for viral infection. (B) The infected cells with recombinant virus at an MOI of 20 were incubated at $30^{\circ} \mathrm{C}$ for 4 days. The intracellular activity of $\beta$-galactosidase was measured by the method described of Miller (1972).

level, indicating the absence of a "culture age" effect. However, $\beta$-galactosidase activity declined rapidly in final product yield after 8 days p.i. (VI, Fig. 2B).

\section{Effect of cell density on $\boldsymbol{\beta}$-galactosidase expression}

Determination of optimal cell density for infection is an essential factor in the efficient use of the baculovirus system for recombinant protein production. Figure 3 shows the effects of cell density ranging from $2.0 \times 10^{5}$ to $2.0 \times 10^{7}$ cells/flask at the time of infection on $\beta$-galactosidase expression. Cell viabilities declined within several days after infection (data not shown). The expressed $\beta$-galactosidase activity on a culture volume basis was the highest when the insect cells were infected at $2.0 \times 10^{6}$ cells/flask, and 


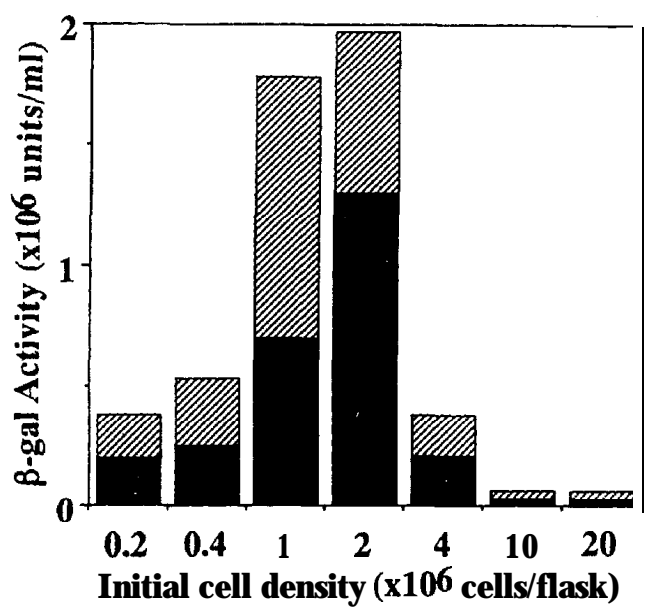

Fig. 3. Effect of Cell Density on ,3-Galactosidase Expression.

Sf 21 cells in the late exponential phase of growth were harvested, suspended in fresh medium at various cell densities, infected with recombinant virus at an $\mathrm{MOI}$ of 20 , and incubated at $30^{\circ} \mathrm{C}$ for 4 days. Intra- $(\square)$ and extracellular ( $\square$ ) enzyme activities were assayed according to the method described in the text.

declined sharply when the cell density was further increased.

\section{E ffect of MOI on $\beta$-galactosidase expression}

The effects of MOI, ranging from 0 to 600 , on the yields of $\beta$-galactosidase were determined. Final $\beta$-galactosidase activity as a function of MOI is presented in Fig. 4. The increase in final product was observed for MOI values greater than 4 in cultures infected with recombinant virus. The maximum yield of recombinant protein occurred in the infected cells with a MOI of 10 . If MOI was higher than 100 , cell viability decreased in proportion to the MOI (data not shown), leading to a slight decrease in final products.

\section{DISCUSSION}

In order to develop an efficient process for recombinant protein production, various factors which affect the productivity of Sf21 insect cells when using the baculovirus expression system were investigated. The final yield of cloned $\beta$-galactosidase by the infected Sf21 cells was affected by the serial passage of recombinant baculovirus and MOI. Especially, the repetition of passage of recombinant baculovirus resulted in a sharp decrease in $\beta$-galactosidase productivity, and the expressed enzyme activity obtained 


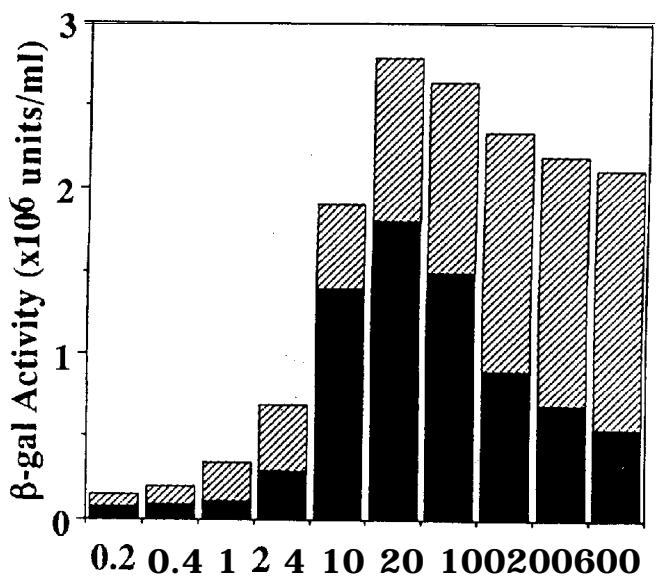

Fig. 4. 3 -Galactosidase Expression Level by $\mathrm{Sf} 21$ Cells Infected with Various MOIs.

Sf2 1 cells $\left(2.0 \times 10^{\mathrm{k}}\right.$ cells $\left./ \mathrm{ml}\right)$ were infected with various MOIs, and incubated at $30^{\circ} \mathrm{C}$ for 4 days. The intra- $(\square)$ and extracellular ( $\square$ ) enzyme fractions were prepared and assayed.

with 11th-passage virus dropped one forith of that obtained with 5th-passage (Fig. 1B). The decrease of virion formation was observed by the infected insect cells with AcNPV. Therefore, the decrease in recombinant protein productivity might due to the propagation of baculovirus itself.

A significant difference in the enzyme activity of $\beta$-galactosidase expressed by the infected Sf2 1 cells was not detected at any cell stage of the growth. The $\beta$-galactosidase activity on a culture volume basis showed a sharp increase in was extremely influenced with the initial cell density. However, the enzyme activity on a per cell basis was found to be almost same beyond $2 \times 10^{6}$ cells/ml. Lindsay and Betenbaugh (1992) stated that insect cells generated higher product yields when infected with recombinant baculovirus at low ceil densities $(3 \times 10$ " cells $/ \mathrm{ml})$ than at high cell densities $\left(9 \times 10^{5} \mathrm{cells} / \mathrm{ml}\right)$. These results indicate that MOI might be quite important as a factor affecting recombinant protein expression in baculovirus insect cell system.

Lazarte et al. (1992) reported that the infection at high MOI of 580 allowed an efficient recombinant protein production by infected Sf9 cells with AcCD4 encoding the full length human CD4. However, as shown in Fig. 4 in this work, the $\beta$-galactosidase productivity by infected Sf21 cells at higher MOI than 100 resulted in decrease remarkably. Licari and Bailey (1992) reported that it is more feasible to infect the culture earlier in the exponential phase with a lower MOI (e.g., 0.1) and obtain the final product concentrations of the same order of magnitude as that by the infection with an MOI of 100. It seems that, by using a lower MOI and relying on secondary infection of the culture (Schopf et al., 1990), the amount of stock virus needed will be substantially reduced. However, the higher enzyme productivity at a lower MOI than 1 has not been observed 
with recombinant virus in this study (Fig. 4). At an MOI of 10, the $\beta$-galactosidase activity expressed by the infected $\mathrm{Sf} 21$ cells amounted to the highest. Therefore, it is quite interesting that the suitable range of MOI for recombinant protein production by Ac360-501 $\beta$-gal-infected Sf2 1 cells was found to be very narrow as between 4 and 20 .

To improve the product yields from a biochemical engineering perspective, it will try to achieve the mass production of E.coli $\beta$-galactosidase in the stirred vessels.

\section{REFERENCES}

Hara, T., K. Nonaka, N. Etou, S. Ogata, and T. Kawarabata 1992 Production of Escherichiacoli $\beta-$ galactosidase by baculovirusinsect cell system. Biosci. Biotech. Biochern., 56: 1124-1 125

Hara, T., K. Nonaka, H. Kawaguchi, S. Ogata, and N. Etou 1993 Effect of temperature on Escherichia coli $\beta$-galactosidase expression in baculovirus-insect cell system. Biosci.Biotech. Biochem., 57: 996-997

Hink, W. F., D. R. Thomsen, D. J. Davidson, A. L. Meter, and F. J. Castellino 1990 Expression of three recombinant proteins using baculovirus vectors in 23 insect cell lines. Biotechnol. Prog., 7: 9-14

Kuchler, R. J. 1977 Biochemical Methods in Cell Culture and Virology. Dowden, Hutchinson \& Ross, Inc., Stroudsburg, Penn. (U.S.A.)

Lazarte, J. E., P. F. Tosi, and C. Nicolau 1992 Optimization of full-length rCD4 in baculovirus-infected Sf9 cells. Biotech nol. Bioeng., 40: 214-217

Licari, P. and J. E. Bailey 1992 Production of a discrete, hetero- geneous polulation of $\beta$-galactosidase polypeptides using baculovirus expression vectors. Biotechnol.Bioeng., 39: 932-944

Lindsay, D. A. and M. J. Betenbaugh 1992 Quantification of cell culture factors affecting recombinant protein yields in baculovirus-infected insect cells. Biotechnol Bioeng., 39: 614-618

Maiorella, B., D. Inlow, A. Shauger, and D. Harano 1988 Large-scale insect cell-culture for recombinant protein production. Bio/Technology, 6: 1406-1410

Miller, L. K. 1972 Experimentsin Molecular Genetics. Cold Spring Harbor Laboratory, Cold Spring Harbor, N.Y. (U.S.A.)

Murhammer, D. W. and C. F. Goochee 1988 Scale-up of insect cell cultures: protective effects of pluronic F-68. Bio/Technology, 6: 1411-1418

Schopf, B., M. W. Howaldt, and J. E. Bailey 1990 DNA distribution and respiratory activity of Spodoptera frugiperda populations infected with wild-type and recombinant Autographacalifomica nuclear polyhedrosis virus. J.Biotechnol., 15: 169-186

Stockdale, H. and G. R. Gardiner 1977 The influence of the condition of cells and medium on production of polyhedra of Autographacalifomica nuclear polyhedrosis virus in vitro. J.Imn.Pathol., 30: 330336

Summers, M. D. and G. E. Smith 1987 A manual of methods for baculovirus vectors and insect cell culture procedures. Texas Agr. Exp. Stn. Bull., (1555): 10-18

Vaughn, J. L., R. H. Goodwin, G. L. Tompkins, and P. McCawley 1977 The establishment of two insect cell lines from the insect Spodoptera frugiperda (Lepidoptera: Noctuidae). In Vitro, 13: 213-217

Wiss, S. A., D. Pelow, G. C. Smith, J. L. Vaughn, and E. Dougherty 1986 Techniques in setting up and maintenance of tissue and cell culture. In "The Bilogy of Baculovirus," ed. by C. Kurstak, Elsevier Biomedical, Ireland

Wood, H. A., L. B. Johnston, and J. P. Burand, 1982 Inhibition of Autographacalifornica nuclear polyhedrosis virus replication in high-density Trichoplusia ni cell cultures. Virology, 119: 245-254 